\title{
An Investigation into the Relevance of Present M.Ed. Curriculum in the Universities of Chhattisgarh State
}

\author{
Mr. Jubraj Khamari* Dr. S.N. Mahapatra** \\ * Deptt. Of School Of Education, MATS University, Gullu, Arang, Raipur, (C.G) - INDIA, \\ ** Deptt. Of DPIASE, Beherampur University, Bhanja Bihar, Beherampur, Odisha-INDIA,
}

\begin{abstract}
Curriculum can be conceived as experience organized through language into patterns of thoughts (or structures of concepts) thus creating meaning, which in turn helps us understand the world we live in."To make the proposed paradigm shift a reality, NCF - 2005 rightly felt and came out with curricular and process oriented changes in teacher education. Keeping this nature and vision in view, NCERT, in collaboration with NCTE, developed a draft curriculum for teacher education largely reflecting the NCF-2005 philosophy of schooling and teacher development. The draft Curriculum framework developed by the NCTE in 2006, collaboration with the NCERT, has shown numerous concerns for the re-structuring of teacher education curriculum. As is generally the tendency with our experts the report of framework is overloaded with concerns, resulting suggestions and their implementation. At the same time there are many new ideas, which, if implemented, will bring about a change for the modernization of curriculum content. Researcher feels more and more about the curriculum of teacher educators (M.Ed. Scholars) in the universities of Chhattisgarh state in the present context. Hence researcher states the problem.
\end{abstract}

Keywords: The Chhattsgarh state, the present M.Ed. curriculum, The relevance, The Universities.

\section{Introduction}

"Curriculum can be conceived as experience organized through language into patterns of thoughts (or structures of concepts) thus creating meaning, which in turn helps us understand the world we live in."

To make the proposed paradigm shift a reality, NCF - 2005 rightly felt and came out with curricular and process oriented changes in teacher education.

Keeping this nature and vision in view, NCERT, in collaboration with NCTE, developed a draft curriculum for teacher education largely reflecting the NCF-2005 philosophy of schooling and teacher development.

The key features of teacher education curriculum and the continued professional development of practicing teachers that could enable the realization of the future of a state. Hence NCF-2005 deliberated upon and came out with systemic concerns and needs:

In order to make teacher education vibrant and also responsive to the emerging demands the field, it is necessary to change, to make a definite, recognizable shift in the direction to be held, and to able to realize such expectations, teacher education has to comprise its pupil teachers.

The draft Curriculum framework developed by the NCTE in 2006, collaboration with the NCERT, has shown numerous concerns for the re-structuring of teacher education curriculum. As is generally the tendency with our experts the report of framework is overloaded with concerns, resulting suggestions and their implementation. At the same time there are many new ideas, which, if implemented, will bring about a change for the modernization of curriculum content.

Teacher has always played a crucial role in preparing communities and societies towards exploring new horizons and achieving higher levels of progress and development. They are the prime agents of change. The significance of the emerging role of teachers has never been as critical as it is at this juncture. Professionalism in teacher education has been a matter of concern and attention in India. Teacher education is attracting more and more attention of the society as numerous NGOs have come forward to establish institutions.

The three-tier system of teacher education is found to be highly effective to coordinate the activities of teacher training institutions. These three-tier systems include: Pre-primary/Nursery, Primary/Elementary and Secondary.

Therefore researcher feels more and more about the curriculum of teacher educators (M.Ed., Scholars) in the universities of Chhattisgarh state in the present context. Hence researcher states the problem - "AN INVESTIGASTION INTO THE RELEVANCE OF PRESENT M.Ed. CURRICULUM IN THE UNIVERSITIES OF CHATTISGARH STATE” 


\subsection{The Relevance:}

\section{The Operational Meaning}

The relevance means the 'Justification' of M.Ed. Curriculum in University of Chhattisgarh. It means the justification of curriculum by the means of 'Meaning Making Process' as per the recent innovation in the National Council of Teacher Education \& National Council of Education Research and Training Bhopal (M.P.).

The relevance means the Justification of utilization of curriculum on the basis of primary teacher to secondary teacher by the teacher educator i.e. 'Constructivism' in the name of 'Course Objectives'.

\subsection{The Present M.Ed. Curriculum}

"Curriculum is a tool in the hand of the artist (teachers) to mould his materials (Pupils) according to his ideals (Objectives) in his Studio (School)."

The present M.Ed. curriculum means-

-Cunninghum

$$
\begin{aligned}
& \text { CURRICULUM M.Ed. CODE - } 131 \\
& \text { REVISED ORDINANCE NO. } 31
\end{aligned}
$$

M.Ed. syllabus or the courses of studies $(2008$ - 2013) prevailing in different colleges under Pt. Ravishankar Shukla University \& Guru Ghasidas University Chhattisgarh. The curriculum approved by National Council of Teacher Education under Bhopal Zone New Delhi.

\subsection{The State Chhattisgarh}

"A new Chhattisgarh - VISION-2020- A knowledge Society"

- K.D.P. Rao, IAS

The Chhattisgarh state occupies an important role in the rich cultural heritage of India in the world. So here researcher states on the problem of study in the state of Chhattisgarh, does not free from improvement of primary to secondary education and to make the primary and secondary education meaningful the state has to go through the relevance of present M.Ed. curriculum because Chhattisgarh has the reflection of strata of school system and teacher education program is a three tire system. Therefore the researcher has given the operational meaning of the state THE CHHATTISGARH STATE which proves the historical fact and geographical phenomena into a real one.

\subsection{The Universities}

"Flight to Excellence"

- Government of Chhattisgarh 2008 - 2013

In the present study the researcher used a word with the definite article the i.e. in the Universities means only two University in Chhattisgarh state under which there are several colleges where M.Ed. curriculum is going on -

1. Pt. Ravisankar Shukla University, Raipur Chhattisgarh.

2. Guru Ghasidas Central University, Bilaspur Chhattisgarh.

\section{OBJECTIVES}

The main objectives of the study are the following:

1. To find out the defect and deficiency of present M.Ed. curriculum in the universities of Chhattisgarh state.

2. To find out the aspect and efficiency of present M.Ed. curriculum in the universities of Chhattisgarh state.

\section{METHOD}

The researcher follows the Normative Survey Method to complete the study successfully.

\section{POPULATION}

All the M.Ed. scholars, all the Teacher Educators (Lecturer/ Reader/Professor), all retired Teacher Educators (Experts) \& Director and Joint Director of Directorate of T.E. and SCERT of the Chhattisgarh state constituted the population of the study.

\section{SAMPLE}

For the present study the researcher has taken two hundred (200samples) samples selecting through random sampling technique out of total population delimited as the present study. 


\section{TOOLS}

So far as the present study is concerned the researcher has prepared a four point scaled questionnaire to collected required data followed by all the three steps of test construction. The questionnaire consisted of two parts like- Part-I, Part-II as comprised to two objectives of the study comprised 16 statements on M.Ed. Curriculum as.

\section{Part-I}

$\begin{array}{llll}\text { a) Objective-1 } \quad \text { Items No.1 to Items No.8 } & = & 8 \text { statements } \\ \text { Part-II } & & \\ \text { b) Objective-2 } \quad: \text { Items No.9 to Items No.16 } & = & 8 \text { statements } \\ \text { Objectives } 1 \text { to } 2: \text { Items No. } 1 \text { to Items No. } 16 & = & 16 \text { statements }\end{array}$

\section{STATISTICAL TECHNIQUE}

The researcher used simple percentage method as statistical technique as the tool is based on four point scale for proper scoring and analysis of data so far as the nature of the study is concerned the researcher categorized the total sample in three categories as category I $=75$ sample, category II $=75$ sample and category III $=50$ sample.

\section{Admission in M.Ed. Curriculum}

\section{Analysis and Interpretation of Data}

Both career and entrance examination should be taken into consideration for selecting a candidate to take admission into M.Ed. course because-

\begin{tabular}{|l|l|l|l|l|l|l|}
\hline SI.No. & Answers & Cat.-I & Cat.-II & Cat.-III & Total & $\mathbf{\%}$ \\
\hline a. & Provides job facilities & 22 & 29 & 21 & 72 & 36 \\
\hline b. & Collects good students & 19 & 15 & 10 & 44 & 22 \\
\hline c. & Uniformity in intellect & 20 & 19 & 11 & 50 & 25 \\
\hline d. & Not academic but professional & 14 & 12 & 08 & 34 & 17 \\
\hline
\end{tabular}

From the above table it is found that-

$17 \%$ of teacher educators opined that it is not academic but professional.

$22 \%$ of teacher educators opined that it collects good students.

$25 \%$ of teacher educators opined that it gives uniformity in intellect.

$36 \%$ of teacher educators opined that it provides job facility.

Hence it is concluded that majority of the teacher educator has given the opinion that it job facility and gives uniformity in intellect.

\section{SELECTION PROCEDURE}

Central selection through S.C.E.R.T. on the basis of provision for reservation should be taken into consideration during admission system because-

TABLE -2

\begin{tabular}{|l|l|l|l|l|l|l|}
\hline SI.No. & Answers & Cat.-I & Cat.-II & Cat.-III & Total & \% \\
\hline a. & Reservation Quota & 22 & 20 & 14 & 56 & 28 \\
\hline b. & Each category & 30 & 25 & 21 & 76 & 38 \\
\hline c. & Age criteria & 15 & 20 & 15 & 50 & 25 \\
\hline d. & Professional course & 08 & 10 & 0 & 18 & 09 \\
\hline
\end{tabular}

From the above table it is found that-

$09 \%$ of teacher educators opined that it is professional course.

$25 \%$ of teacher educators opined that age should be a criterion for admission.

$28 \%$ of teacher educators opined that reservation quota should be given.

$38 \%$ of teacher educators opined that candidate of his category should be given chances.

Hence it concluded that majority of teacher educators opined that selection procedure should be proceed on the basis on age, reservation quota \& each categories of candidates. 


\section{AREA OF SPECIALIZATION}

There should not be elective subject area of specialization in M.Ed. curriculum-

\begin{tabular}{|c|c|c|c|c|c|c|}
\hline \multicolumn{7}{|c|}{ TABLE -3 } \\
\hline SI.No. & Answers & Cat.-I & Cat.-II & Cat.-III & Total & $\%$ \\
\hline a. & Mastery in each area & 30 & 23 & 19 & 72 & 36 \\
\hline b. & It is Mastery course & 18 & 17 & 11 & 46 & 23 \\
\hline c. & A professional course & 12 & 15 & 09 & 36 & 18 \\
\hline $\mathrm{d}$. & Mastery in each subjects & 15 & 20 & 11 & 46 & 23 \\
\hline
\end{tabular}

From the above table it is found that-

$18 \%$ of teacher educators opined that it is a professional course.

$23 \%$ of teacher educators opined that it is a mastery course or it gives mastery in each subjects. curriculum.

$36 \%$ of teacher educators opined that it is necessary to acquire mastery in each area of subject of M.Ed.

Hence it is concluded that mastery has to acquire in each areas of subjects in M.Ed. curriculum.

\section{ELECTIVE SUBJECT}

Elective subject only give mastery in one subject area because-

\begin{tabular}{|c|c|c|c|c|c|c|}
\hline \multicolumn{7}{|c|}{ TABLE -4 } \\
\hline SI.No. & Answers & Cat.-I & Cat.-II & Cat.-III & Total & $\%$ \\
\hline a. & Confined two subjects & 25 & 26 & 17 & 68 & 34 \\
\hline b. & Mastery in two subjects & 20 & 19 & 13 & 52 & 26 \\
\hline c. & Special talent on the area & 15 & 15 & 10 & 40 & 20 \\
\hline d. & Elective subject & 15 & 15 & 10 & 40 & 20 \\
\hline
\end{tabular}

From the above table it is found that-

$20 \%$ of teacher educators opined that it makes effective only in elective subject.

$20 \%$ of teacher educators opined that it gives mastery only in special paper.

$26 \%$ of teacher educators opined that it does gives mastery in two subjects only.

$34 \%$ of teacher educators opined that it is confined to only two subjects (paper).

Hence it is concluded that majority of the teacher educator reveals the fact that elective subject is confined only two subjects area.

\section{M.Ed. CURICULUM EXAMINATION}

M.Ed. curriculum examination should cover to each and every units of each paper-

From the above table it is found that-

$22 \%$ of teacher educators opined that it fulfils aspect of M.Ed. curriculum.

$22 \%$ of teacher educators opined that it makes effective to teacher educator.

$24 \%$ of teacher educators opined that it provides subject mastery.

$32 \%$ of teacher educators opined that each and every units of each paper has its own important.

Hence it is concluded that majority of the teacher educator has given their opinion that each and every units of each paper of M.Ed. curriculum has its own important.

\section{M.Ed. CURRICULUM EXAMINATION}

M.Ed. examination should be in the way of both theoretical \& practical because-

\begin{tabular}{|c|c|c|c|c|c|c|}
\hline \multicolumn{7}{|c|}{ TABLE -6 } \\
\hline SI.No. & Answers & Cat.-I & Cat.-II & Cat.-III & Total & $\%$ \\
\hline a. & A professional course & 19 & 17 & 12 & 48 & 24 \\
\hline b. & Teaching based Art & 30 & 24 & 18 & 72 & 36 \\
\hline c. & Practical \& theoretical course & 10 & 23 & 11 & 44 & 22 \\
\hline d. & Provides effectiveness & 16 & 11 & 09 & 36 & 18 \\
\hline
\end{tabular}


From the above table it is found that-

$18 \%$ of teacher educators opined that it provides effectiveness of teacher educators.

$22 \%$ of teacher educators opined that it is practical \& theoretical course.

$24 \%$ of teacher educators opined that it is a professional course.

$36 \%$ of teacher educators opined that it is teaching based Art.

Hence it is concluded that majority of the teacher educators opined that it is teaching based Arts.

\section{PHILOSOPHICAL \& SOCIOLOGICAL FOUNDATION OF EDUCATION}

Philosophical and Sociological Foundation of Education should be taught in M.Ed.-

TABLE - 7

\begin{tabular}{|l|l|l|l|l|l|l|}
\hline SI.No. & Answers & Cat.-I & Cat.-II & Cat.-III & Total & \% \\
\hline a. & Philosophical knowledge & 25 & 20 & 15 & 60 & 30 \\
\hline b. & Philosophical idea & 17 & 22 & 13 & 52 & 26 \\
\hline c. & Contribution of great man & 12 & 12 & 08 & 32 & 16 \\
\hline d. & To build personality & 21 & 21 & 14 & 56 & 28 \\
\hline
\end{tabular}

From the above table it is found that-

$16 \%$ of teacher educators opined that it should be taught to learn to the contribution of great man.

$26 \%$ of teacher educators opined that it provides philosophical ideas in the mind of pupils teachers.

$28 \%$ of teacher educators opined that it to build personality of teacher educator

$30 \%$ of teacher educators opined that philosophical knowledge is required to be an effective teacher educator.

Hence it is concluded that majority of teacher educators reveals that philosophical knowledge is required to be an effective teacher educators.

\section{SOCIOLOGICAL FOUNDATION OF EDUCATION}

Knowledge of sociological foundation of education required to M.Ed. scholars-

TABLE -8

\begin{tabular}{|l|l|l|l|l|l|l|}
\hline SI.No. & Answers & $\begin{array}{l}\text { Cat.- } \\
\text { I }\end{array}$ & $\begin{array}{l}\text { Cat.- } \\
\text { II }\end{array}$ & $\begin{array}{l}\text { Cat.- } \\
\text { III }\end{array}$ & Total & $\%$ \\
\hline a. & Status of the society & 20 & 10 & 10 & 40 & 20 \\
\hline b. & In the changing society & 30 & 39 & 23 & 92 & 46 \\
\hline c. & In the social bases & 12 & 12 & 08 & 32 & 16 \\
\hline d. & Well social being & 13 & 14 & 09 & 36 & 18 \\
\hline
\end{tabular}

From the above table it is found that-

$16 \%$ of teacher educators opined that it is to great influence in the sociological bases.

$18 \%$ of teacher educators opined that it required to M.Ed. scholars to make thoughtful well social being.

$20 \%$ of teacher educators opined that it required knowing the status of the society.

$46 \%$ of teacher educators opined that it is required to well adjust in the changing society.

Hence it is concluded that majority of the teacher educators opined that knowledge of sociological foundation of education required to M.Ed. scholar to well adjust in the changing society in present context.

PSYCHOLOGICAL FOUNDATION OF EDUCATION

Psychological foundation of education should be in M.Ed. curriculum because-

TABLE -9

\begin{tabular}{|l|l|l|l|l|l|l|}
\hline SI.No. & Answers & Cat.-I & Cat.-II & Cat.-III & Total & \% \\
\hline a. & Facilitate teaching learning & 21 & 30 & 17 & 68 & 34 \\
\hline b. & The growth and dev. Learners & 18 & 09 & 09 & 36 & 18 \\
\hline c. & Intellect and characteristics & 12 & 21 & 11 & 44 & 22 \\
\hline d. & Develop own personality & 24 & 15 & 13 & 52 & 26 \\
\hline
\end{tabular}

From the above table it is found that-

$18 \%$ of teacher educators opined that psychological foundation of education should be in M.Ed. curriculum to know the growth and development of learners. 
$22 \%$ of teacher educators opined that it is to know the intellect and characteristic of learner.

$26 \%$ of teacher educators opined that it to develop own personality of teacher educator.

$34 \%$ of teacher educators opined that it is to facilitate teaching learning process.

Hence it is concluded that majority of teacher educator opined that psychological foundation of education is to facilitate teaching learning process.

\section{PSYCHOLOGICAL FOUNDATION OF EDUCATION}

Psychological foundation of education helps the pupil teacher-

TABLE -10

\begin{tabular}{|l|l|l|l|l|l|l|}
\hline SI.No. & Answers & $\begin{array}{l}\text { Cat.- } \\
\text { I }\end{array}$ & $\begin{array}{l}\text { Cat.- } \\
\text { II }\end{array}$ & $\begin{array}{l}\text { Cat.- } \\
\text { III }\end{array}$ & Total & $\%$ \\
\hline a. & Entry behavior of learner & 11 & 10 & 07 & 28 & 14 \\
\hline b. & Psychological principle & 28 & 29 & 19 & 76 & 38 \\
\hline c. & $\begin{array}{l}\text { General principle of } \\
\text { teaching }\end{array}$ & 25 & 23 & 16 & 64 & 32 \\
\hline d. & Maxims of teaching & 11 & 13 & 08 & 32 & 16 \\
\hline
\end{tabular}

From the above table it is found that-

$14 \%$ of teacher educators opined that it is to test the entry behavior of learner.

$16 \%$ of teacher educators opined that it is to provide maxims of teaching.

$32 \%$ of teacher educators opined that it is to provide general principal of teaching.

$38 \%$ of teacher educators opined that it is to provide psychological principles of teaching.

Hence it is concluded that majority of teacher educators opined that psychological foundation of education helps the pupil teachers to provide psychological principle of teaching.

\section{METHOLOGY OF EDUCATIONAL RESEARCH}

Methodology of educational research helps the M.Ed. scholar to make the pupil-

TABLE -11

\begin{tabular}{|l|l|l|l|l|l|l|}
\hline SI.No. & Answers & $\begin{array}{l}\text { Cat.- } \\
\text { I }\end{array}$ & $\begin{array}{l}\text { Cat.- } \\
\text { II }\end{array}$ & $\begin{array}{l}\text { Cat.- } \\
\text { III }\end{array}$ & Total & \% \\
\hline a. & Teachers methodological & 12 & 21 & 11 & 44 & 22 \\
\hline b. & Teacher research full & 39 & 30 & 23 & 92 & 46 \\
\hline c. & Teacher fact full & 12 & 15 & 09 & 36 & 18 \\
\hline d. & Teacher data base & 12 & 09 & 07 & 28 & 14 \\
\hline
\end{tabular}

From the above table it is found that-

$14 \%$ of teacher educators opined that it is to make the teacher educator data base.

$18 \%$ of teacher educators opined that it is to make pupil teacher educator fact full.

$22 \%$ of teacher educators opined that it is to make the pupil teacher methodological.

$46 \%$ teacher educators opined that it is to make the pupil teacher research full.

Hence majority of teacher educators opined that methodology of educational research helps the M.Ed. scholars to make the pupil teachers methodological.

\section{METHOLOGY OF EDUCATIONAL RESEARCH}

Methodology of educational research helps the teacher educator to make the pupil-

\begin{tabular}{|c|c|c|c|c|c|c|}
\hline \multicolumn{7}{|c|}{ TABLE -12 } \\
\hline SI.No. & Answers & Cat.-I & Cat.-II & Cat.-III & Total & $\%$ \\
\hline a. & Teacher suggestive & 13 & 14 & 09 & 36 & 18 \\
\hline b. & Tool and technique based & 27 & 09 & 12 & 48 & 24 \\
\hline c. & Teacher fact oriental & 12 & 30 & 14 & 56 & 28 \\
\hline d. & Teacher analytical & 23 & 22 & 15 & 60 & 30 \\
\hline
\end{tabular}

From the above table it is found that-

$18 \%$ of teacher educators opined that it is to make pupil teachers suggestive.

$24 \%$ of teacher educators opined that it is to make pupil teachers tool and technique based.

$28 \%$ of teacher educators opined that it is to make pupil teachers fact oriental.

$30 \%$ of teacher educators opined that it is to make pupil teachers analytical. 
Hence it is concluded that majority of teacher educator opined that methodology of educational research helps the teachers educator to make the pupil teachers analytical.

\section{GUIDANCE \& COUNSELING}

Guidance \& counseling helps the M.Ed. scholar to make the pupil teacher-

TABLE -13

\begin{tabular}{|l|l|l|l|l|l|l|}
\hline SI.No. & Answers & Cat.-I & Cat.-II & Cat.-III & Total & \% \\
\hline a. & Teachers guide full & 07 & 11 & 06 & 24 & 12 \\
\hline b. & Teacher job oriental & 35 & 43 & 26 & 104 & 52 \\
\hline c. & Teacher information center & 17 & 13 & 10 & 40 & 20 \\
\hline d. & Teacher a counselor & 16 & 08 & 08 & 32 & 16 \\
\hline
\end{tabular}

From the above table it is found that-

$12 \%$ of teacher educators opined that it is to make pupil teacher guide full.

$16 \%$ of teacher educators opined that it is to make pupil teacher a counselor.

$20 \%$ of teacher educators opined that it is to make pupil teacher information center.

$52 \%$ of teacher educators opined that it is to make pupil teacher job oriental.

Hence it is concluded that majority of the teacher educators opined that guidance and counseling helps the M.Ed. scholar to make the pupil teacher job oriental.

\section{GUIDANCE \& COUNSELING}

Guidance \& counseling helps the M.Ed. scholar to make the pupil teacher-

TABLE -14

\begin{tabular}{|l|l|l|l|l|l|l|}
\hline SI.No. & Answers & $\begin{array}{l}\text { Cat.- } \\
\text { I }\end{array}$ & $\begin{array}{l}\text { Cat.- } \\
\text { II }\end{array}$ & $\begin{array}{l}\text { Cat.- } \\
\text { III }\end{array}$ & Total & $\%$ \\
\hline a. & Teacher problem solving & 24 & 21 & 15 & 60 & 30 \\
\hline b. & Teacher self confidence & 18 & 21 & 13 & 52 & 26 \\
\hline c. & Teacher self efficient & 14 & 10 & 08 & 32 & 16 \\
\hline d. & Teacher self service & 19 & 23 & 14 & 56 & 28 \\
\hline
\end{tabular}

From the above table it is found that-

$16 \%$ of teacher educators opined that it is to make pupil teacher self efficient.

$26 \%$ of teacher educators opined that it is to make pupil teacher self confidence.

$28 \%$ of teacher educators opined that it is to make pupil teacher self service.

$30 \%$ of teacher educators opined that it is to make pupil teacher problem solving.

Hence it is concluded that majority of the teacher educator opined that guidance \& counseling helps the M.Ed. scholar to make the pupil teacher problem solving.

\section{DISTANCE EDUCATION}

Distance education should be a paper in M.Ed. curriculum because-

TABLE -15

\begin{tabular}{|l|l|l|l|l|l|l|}
\hline SI.No. & Answers & Cat.-I & Cat.-II & $\begin{array}{l}\text { Cat.- } \\
\text { III }\end{array}$ & Total & \% \\
\hline a. & Different kind of information & 09 & 06 & 05 & 20 & 10 \\
\hline b. & Communication technologies & 13 & 17 & 10 & 40 & 20 \\
\hline c. & Improve technology process & 23 & 22 & 15 & 60 & 30 \\
\hline d. & Need of distance learning & 30 & 30 & 20 & 80 & 40 \\
\hline
\end{tabular}

From the above table it is found that-

$10 \%$ of teacher educators opined that it is to explore different kind of information.

$20 \%$ of teacher educators opined that it is to develop communication technologies.

$30 \%$ of teacher educators opined that it is to improve technological process.

$40 \%$ teacher educators opined that it is to study the nature $\&$ needs of distance learning.

Hence it is concluded that majority of teacher educators opined that distance education should be a paper in M.Ed. curriculum to study the nature and needs of distance learning. 


\section{DISTANCE EDUCATION}

Distance education helps to M.Ed. scholar-

\begin{tabular}{|c|c|c|c|c|c|c|}
\hline \multicolumn{7}{|c|}{ TABLE -16 } \\
\hline SI.No. & Answers & Cat.-I & Cat.-II & Cat.-III & Total & $\%$ \\
\hline a. & Student supporting service & 10 & 08 & 06 & 24 & 12 \\
\hline b. & Correspondence program & 25 & 23 & 16 & 64 & 32 \\
\hline c. & Distance education & 21 & 30 & 17 & 68 & 34 \\
\hline d. & Informal education & 19 & 14 & 11 & 44 & 22 \\
\hline
\end{tabular}

From the above table it is found that-

$12 \%$ of teacher educators opined that it is to understand student supporting service.

$22 \%$ of teacher educators opined that it is to improve informal education.

$32 \%$ of teacher educators opined that it is to manage different correspondence program.

$34 \%$ of teacher educators opined that it is to enhance good deal of distance education.

Hence it is concluded that majority teacher educator opined that distance education helps to M.Ed. scholar to enhance good deal of distance education program.

\section{Findings and Conclusion}

1. Majority of teacher educator opined that both career \& entrance examination should be taken into consideration for selecting a candidate to take admission in M.Ed. course to remove the defect and deficiency of present M.Ed. curriculum in the Universities of Chhattisgarh (objectives no -1).

2. Central selection through S.C.E.R.T. on the basis of provision for reservation should be taken into consideration during admission system because reservation Quota are given, candidate of each categories are given chances and Age should be criteria for admission (objective no - 1).

3. There should not be area of specialization in present M.Ed. Curriculum rather each and every elective papers mentioned in present M.Ed. Curriculum should be a compulsory paper each making the duration of present M.Ed. Curriculum into two year to fulfill the aspect and efficiency of teacher educator in the Universities of Chhattisgarh.

4. There should be only one subject having two papers like theoretical and experimental carrying 100 marks each as area of specialization to acquire to mastery of M.Ed. scholar to be an effective teacher educator.

5. M.Ed. Curriculum should cover each and every units of each paper having each unit has its own importance in present M.Ed. Curriculum Examination in the Universities of Chhattisgarh to fulfill the aspect and efficiency of the Curriculum.

6. Philosophical \& Sociological Foundation of Education, Psychological Foundation of Education, Methodological Educational Research, Guidance \& Counseling and --Distance Education papers are subjects to achieve their course objective as to fulfill the aspect and efficiency of present M.Ed. curriculum in the University of Chhattisgarh state.

\section{References}

[1] Best, John \& Prentice, W.,( 1978).Research in Education, New Delhi: Hall of India

[2] Rawat D.S., (1970). Measurement Evaluation and Stastics in education, New Delhi, New Raj Book Depot.

[3] M.Ed. Examination 2008-2013 Courses of study M.Ed. Examination, Pt. Ravishankar Shukla University, Raipur Chhattisgarh.

[4] M.Ed. Examination 2008-2013 Courses of study M.Ed. Examination, Guru Ghasidas University, Bilaspur Chhattisgarh.

[5] T.E. \& S.C.E.R.T. 2008-2013 Prospectus \& rules for admission into B.Ed. \& M.Ed. Courses, Director Teacher Education \& State Council of Education Research and Training, Raipur Chhattisgarh.

[6] R.I.E. Bhopal 2008 Development of Teacher Education Curriculum (B.Ed. \& M.Ed.) 2008 Regional Institute of Education Shyamla Hill Bhopal N.C.T.E. (M.P.).

[7] Dr. Greta J.S. Changing contacts, structures and Concern in teacher education N.C.T.E. Bhopal 155,Aradhna Nagar- 462003 (M.P.)

[8] Dr. Ramesh Babu 2007 Participatory Teacher Education for constructivist class room National Curriculum Frame work 2005. N.C.T.E. Bhopal (M.P.)

[9] N.C.E.R.T. 2000 National Curriculum Frame work for school education National Council of Teacher Education New Delhi.

[10] Dr. Sharma R.A. Curriculum Development and Instruction, Surya Publication Near Govt. Inter College Meerut 250001.

[11] Buch M.B. 1987. Third Survey of Research in Education New Delhi N.C.E.R.T.

[12] Buch M.B. 1983. Fourth Survey of Research in Education N.C.E.R.T. New Delhi.

[13] M.H.R.D. India. National Policy on Education 1986 and Revised Policy on Education 1982 Department of Education Ministry of Human Resource Development Govt of India, New Delhi.

[14] Srivastav K.M. 1982. Effectiveness of Teacher Education Programme. M.B. Buch fourth survey of research in education 1993 P994, N.C.T.E. New Delhi.

[15] N.C.E.R.T. New Delhi. The Curriculum of the Ten Years School and the third Indian year book of education.

[16] N.C.E.R.T. New Delhi. Development of Teacher Education Curriculum at B.Ed., M.Ed. And M.A. in education level organized by

[17] Regional Institute of Education, Bhopal, Mysore, Bhopal and Bhubneshwar, Govt of India.

[18] Prof. Srivastav, G.N. Prakash.Internship in teaching, SEP and School based practicum 2007-08 Regional Institute of Education Shymala Hill, Bopal

[19] Flight to Excellence 2007-08. A New Chhattisgarh- Vision-2020- A Knowledge Society Department of Higher Education, Govt. Of Chhattisgarh. 